\title{
RUMAH GADANG : RUANG DAN BUDAYA MAKAN DALAM SIKLUS HIDUP MASYARAKAT MINANGKABAU
}

\author{
Vania Dwi Amanda Surya, Gregorius Prasetyo Adhitama \\ (vania.dwi16@gmail.com,gregoriusprasetyoadhitama@gmail.com) \\ Program Studi Desain Interior \\ Fakultas Seni Rupa dan Desain \\ Institut Teknologi Bandung \\ Jl. Ganesha No. 10. Lb Siliwangi, Kecamatan Coblong, Kota Bandung, Indonesia
}

\begin{abstract}
ABSTRAK
Masyarakat Minangkabau terkenal dengan budaya makannya melalui makanan khasnya rendang di berbagai restoran Padang. Adanya modernisasi dan media sosial menyebabkan terjadinya perkembangan budaya makan. Akibatnya adalah memudarnya pemahaman realitas budaya makan asli Minangkabau yang mengarah pada keseragaman bentuk desain, terutama pada elemen fisik dan konfigurasi ruang bangunannya. Padahal di tempat asalnya masih dilaksanakan kegiatan makan dengan aturan adat Minangkabau antara lain yaitu "Makan Bajamba". Oleh karena itu, sebelum melihat perkembangan desainnya, perlu dipelajari terlebih dahulu bentuk ruang dan budaya makan masyarakat Minangkabau di tempat asalnya. Adapun masalah utama dari penelitian ini adalah bagaimana hubungan antara ruang dan budaya makan dalam siklus hidup masyarakat Minangkabau yang dilakukan di rumah Gadang. Metode yang digunakan adalah metode campuran dengan pendekatan kualitatif melalui studi kasus pada Rumah Gadang Istano Rajo Alam Tuanku Disambah dan kuantitatif dengan menggunakan analisis space syntax pada dimensi konektivitas dan integrasi. Data didapatkan dari studi literatur, wawancara, dan pengamatan langsung di lapangan pada bagian ruang dan elemen fisik rumah Gadang dalam memfasilitasi kegiatan makannya. Hasilnya adalah ruang-ruang di rumah Gadang secara efektif digunakan dalam memfasilitasi budaya makan dalam siklus hidup masyarakat Minangkabau. Pembagian ruang pada proses kegiatan makan berdasarkan peran wanita dan pria dalam sistem kekerabatan matrilinieal. Area penyantapan terbagi menjadi kelompok-kelompok ruang yang lebih kecil sesuai dengan aturan posisi tempat duduk para pria Minangkabau berdasarkan sistem kekerabatan matrilinieal, ditandai oleh dinding, kolom, dan kain seprah alas makanan. Seluruh ruang tempat pelaksanaan kegiatan makan merupakan ruang sosial tempat terjadinya interaksi yang mencerminkan pepatah adat Minangkabau. Analisis space syntax memperjelas hubungan ruang dan kegiatan makan berdasarkan sistem kekerabatan matrilinieal dan interaksi sosial yang terjadi dengan ruang yang digunakan Untuk penelitian selanjutnya dapat menggunakan analisis space syntax sebagai sudut pandang dalam melihat hubungan antara ruang dan budaya.
\end{abstract}

Kata Kunci: ruang; budaya makan; siklus hidup; masyarakat Minangkabau; rumah Gadang

\section{ABSTRACT}

Padang restaurants with specialty food rendang represent the Minangkabau's eating culture. The effect of modernization and media social in the eating culture has indistinct the origin of Minangkabau's eating culture and leads to the uniformity of design, mostly its space and physical elements in the traditional building. Whereas in the roots, eating activities according to the Minangkabau custom still 
carried out, such as Makan Bajamba. It is essential to study the origin of Minangkabau space and eating culture before learning design development. The main problem is how the relationship between space and eating culture in the life cycle of Minangkabau society carried out at Rumah Gadang. By using a mix-method, a qualitative approach is a case study at Rumah Gadang Istana Rajo Alam Tuanku Disambah and quantitative approaches using space syntax analysis on the dimensions of connectivity and integrity. Data were from literature studies, interviews, and direct observations on how Rumah Gadang facilitated eating activities. The result shows that Rumah Gadang effectively assisted the eating culture in the life cycle of its people. The space configuration in the process of eating activities is following the roles of women and men based on a matrilineal kinship system. The seat position rules for Minangkabau men from the matrilineal kinship system divided Ruang Lepas into smaller areas, marked by walls, columns, and seprah clothes. All space of eating activities is a social space where interactions took place as a reflection of Minangkabau customs. The space syntax analysis clarifies the relationship between space and eating activities based on the matrilineal kinship system and the social interactions that occur with the space used. For future research, the space syntax analysis is useful as a perspective to learn the relationship between space and culture.

Keywords: space; eating culture; life cycle; Minangkabau society; rumah Gadang

\section{PENDAHULUAN}

Salah satu faktor yang membuat masyarakat Minangkabau terkenal adalah budaya makannya. Budaya makan ini dikenal melalui hidangan khasnya rendang di restoran Padang yang tersebar di berbagai daerah dan tentunya dinikmati oleh berbagai kalangan masyarakat (Lipoeto dkk, 2001 dan Franzia dkk, 2015). Padahal rendang sebenarnya merupakan makanan adat sebagai kebanggaan dan kehormatan yang selalu hadir di setiap upacara adat masyarakat Minangkabau (Andam dalam Nurmufida, 2017). Masyarakat Minangakabau memaknai kegiatan makan sebagai bentuk penghormatan terhadap ritual agama dan perayaan siklus hidup yang berperan penting dalam setiap upacara adat (Lipoeto dkk, 2001). Namun, adanya modernisasi, perubahan sosial, dan perkembangan media sosial berperan besar dalam perkembangan budaya makan terutama terkait tempat, waktu, dan jenis makanan (Diaz-Mendez dan van den Broek, 2017, Goodman dkk, 2017, dan Probyn, 2017).

Perkembangan ini dapat menyebabkan memudarnya pemahaman budaya makan asli

Minangkabau, perkembangan desain yang menuju ke arah keseragaman bentuk, dan bahkan hilang (Sari, 2000, Rekarti, 2003, dan Nurti, 2013), terutama pada elemen fisik dan 
konfigurasi ruang dari bangunan tradisional yang memfasilitasi kegiatan makan. Padahal masyarakat Minangkabau masih melaksanakan kegiatan makan berdasarkan adat istiadatnya. Salah satunya adalah Makan Bajamba yang biasanya dilakukan sebagai perayaan pada upacara adat. Oleh karena itu, sebelum melihat perkembangan desainnya, perlu dipelajari terlebih dahulu bentuk ruang dan budaya makan Minangkabau di tempat asalnya. Adapun masalah utama dari penelitian ini adalah bagaimana hubungan antara ruang dan budaya makan masyarakat Minangkabau. Penelitian ini membahas lebih lanjut hubungan tata ruang dan elemen-elemen nonfisik dan fisik bangunan tradisional Minangkabau yaitu Rumah Gadang sebagai tempat tinggal dalam memfasilitasi budaya makannya.

\section{METODE PENELITIAN}

Penelitian ini menggunakan metode campuran dengan pendekatan kualitatif dan kuantitatif dengan menggunakan teknik analisis space syntax pada dimensi konektivitas dan integrasi (Siregar, 2014). Fokus dari penelitian ini yaitu ruang dan elemen fisik lainnya pada Rumah Gadang yang berperan dalam proses pelaksanaan budaya makan masyarakat Minangkabau dalam siklus hidupnya dan hubungan keduanya. Pengamatan dilakukan di Rumah Gadang Istano Rajo Alam Daulat Tuanku Disambah, Sungai Pagu, Solok Selatan, Sumatera Barat, Indonesia (lihat gambar 1). Adapun bangunan tradisional Minangkabau ini dipilih karena merupakan bangunan cagar budaya yang memiliki sejarah dan di daerah tersebut masih kental penerapan adatnya dalam kehidupan sehari-hari.

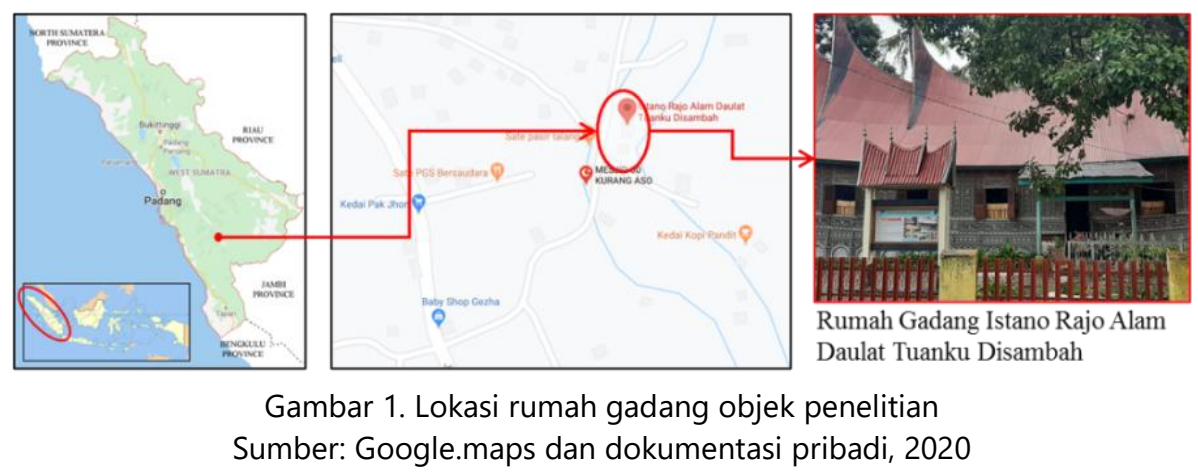


Penelitian ini menggunakan data dari kajian pustaka, wawancara tentang budaya makan Minangkabau dan pengamatan langsung di lapangan pada bagian ruang dan elemen fisik rumah Gadang dalam memfasilitasi kegiatan makannya. Data yang terkumpul diklasifikasikan berdasarkan kegiatan makan sebagai perayaan siklus kehidupan masyarakat Minangkabau dan dalam kehidupan sehari-hari. Upacara adat yang dipilih merupakan representasi dari ketiga fase siklus hidup masyarakat Minangkabau terutama yang dilakukan di Rumah Gadang yaitu Upacara Turun Mandi (K1) perayaan fase kelahiran, Baralek Pernikahan (K2) perayaan fase tumbuh berkembang, dan Mendoa (K3) bagian dari upacara kematian. Kegiatan makan dalam kehidupan sehari-hari terdapat dua yaitu kegiatan makan bersama keluarga (K4) dan menjamu tamu (K5). Data yang telah dikumpulkan kemudian dianalisis dalam beberapa tahap yaitu sebagai berikut.

Tahap 1 : Analisis dari kajian pustaka dan wawancara terhadap elemen-elemen nonfisik budaya makan Minangkabau yang berpengaruh pada ruang-ruang di Rumah Gadang dalam memfasilitasi kegiatan makan, yang meliputi waktu pelaksanaan, orang yang memasak, menyajikan, dan menyantap, tata cara duduk dan makan, jenis makanan utama, dan perannya dalam kehidupan sosial. Tahap 2 : Analisis dari kajian pustaka, wawancara, dan pengamatan langsung di lapangan tentang bagian ruang dan elemen fisik lainnya di Rumah Gadang dalam pelaksanaan kegiatan makan. Tahap 3 : Selanjutnya dilakukan analisis dengan menggunakan teknik space syntax meliputi convex space dan justified graph ketika kegiatan makan berlangsung dengan menggunakan konsep jarak, step depth, untuk menghitung nilai konektivitas dan nilai integrasi (Siregar, 2014). Berdasarkan tahapan tersebut, terdapat beberapa teori-teori yang digunakan sebagai landasan dalam melakukan penelitian, menyusun data hasil penemuan, dan analisis untuk menjawab pertanyaan penelitian.

\section{Kegiatan Makan dalam Budaya Minangkabau}


Kegiatan makan selain sebagai kegiatan pemenuhan kebutuhan hidup juga merupakan kegiatan yang berhubungan dengan perilaku manusia dan menjadi dasar utama dalam kegiatan sosial (Newman, 2009). Menurut Maximillian (2013), makan memiliki tiga fungsi utama yaitu fungsi biologis dalam memenuhi rasa lapar, fungsi sosial sebagai bagian dari kehidupan bersosialisasi, dan fungsi psikologis yang dipengaruhi oleh emosi dan perasaan. Pada pelaksanaan kegiatan makan memiliki tata cara menggunakan peralatan-peralatan dan ruang tertentu. Pada masyarakat dengan perkembangan tinggi maka segala tata cara makan pun akan mempunyai aturan yang kompleks, serta peralatan yang lebih baik dibandingkan dengan masyarakat sederhana yang pola serta aturannya pun cenderung lebih sederhana (Mintosih dan Widiyanto 1996).

Budaya makan masyarakat Minangkabau tentunya tidak lepas dari falsafah adatnya yaitu "Alam Takambang Jadi Guru" dan "Adat Basandi Syarak-Syarak Basandi Kitabullah", di dalamnya juga diatur tata cara pelaksanaan upacara adat dalam siklus hidup mereka. Berdasarkan falsafah tersebut, terdapat pepatah terkait budaya makan yaitu "Bicara selepas haus, berunding sesudah makan". Hal ini membentuk masyarakat Minangkabau untuk menyuguhkan minum dan makanan ringan sebagai layanan menyambut tamu (Rekarti, 2003). Selain itu, pepatah ini juga memiliki arti sebagai dalam melakukan musyawarah harus dalam keadaan kenyang dan tidak lapar. Pepatah ini menjadi landasan pentingnya kegiatan makan pada kehidupan masyarakat Minangkabau bahwa dalam setiap kesempatan dan acara biasanya selalu melibatkan jamuan makan. 


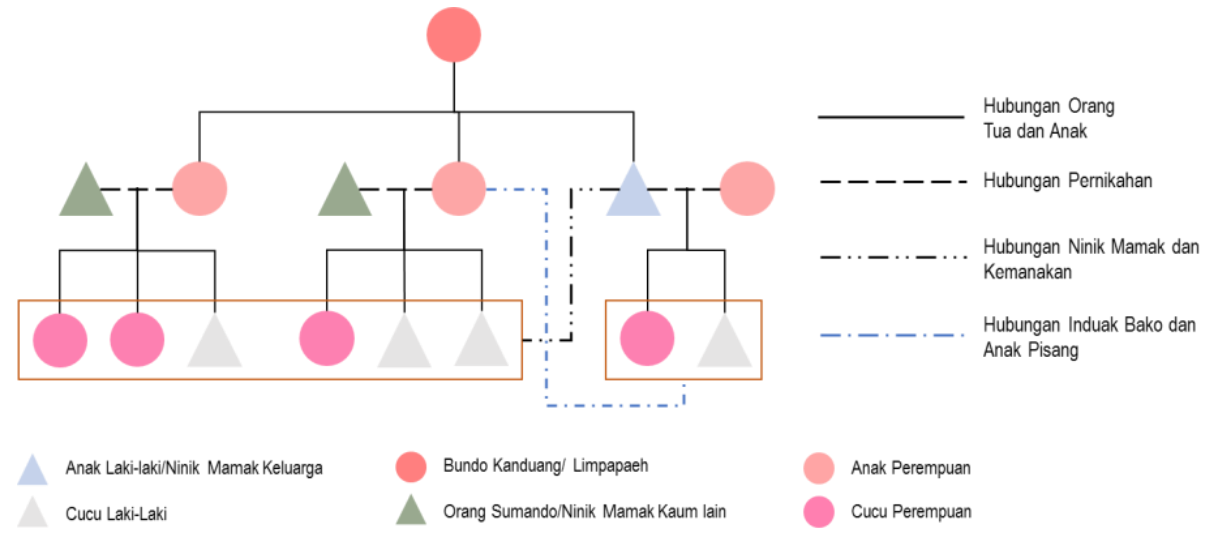

Gambar 2. Diagram ilustrasi hubungan kekerabatan matrilinieal di Minangkabau Sumber: Surya dan Gabe, 2015

Masyarakat Minangkabau menggunakan sistem kekerabatan menurut garis keturunan ibu atau matrilinieal (gambar 2) yang juga dilihat berdasarkan sistem perkawinan di dalam masyarakat (Suarman, 2000, Surya dan Gabe, 2015). Pada sistem ini perempuan memiliki peran penting dalam kehidupan masyarakat dan bertanggung jawab atas segala urusan di dalam keluarga serta penyambung garis keturunan. Laki-laki berperan sebagai mamak untuk memelihara harta pusaka serta menjadi penasihat dan pendengar bagi kemenakannya. Sistem kekerabatan matrilinieal ini menjelaskan peran ninik-mamak, bundo kanduang, dan anak-kemanakan di dalam kehidupan masyarakat. Sistem ini juga menjadi landasan dalam pembagian peran dan tugas mereka dalam proses pelaksanaan kegiatan makan.

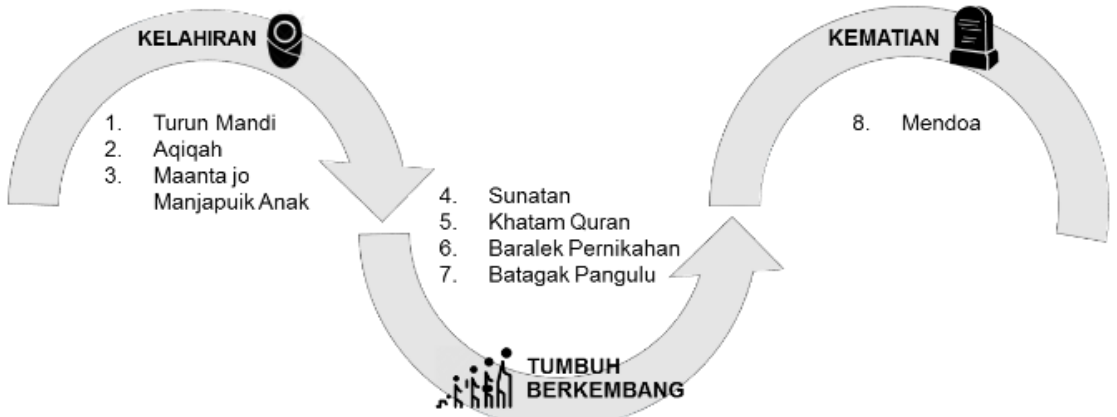

Gambar 3. Diagram ilustrasi upacara adat sebagai perayaan siklus hidup pada masyarakat Minangkabau Sumber: Suarman dkk, 2000 
Pada masyarakat Minangkabau terdapat upacara adat sebagai rasa syukur dalam perayaan siklus kehidupan (kelahiran, tumbuh berkembang, dan kematian) dan ritual agama. Upacara dalam memperingati kelahiran adalah upacara Turun Mandi, Aqiqah, dan Manjapuik jo Maanta Anak. Sunatan, Khatam Quran, Baralek Pernikahan, dan Batagak Pangulu merupakan upacara-upacara adat dalam merayakan ritual agama dan tumbuh berkembangnya kehidupan seorang manusia. Upacara terakhir merupakan upacara memperingati kematian yang juga biasa disebut dengan mendoa yaitu membacakan doa untuk orang yang telah meninggal. Adapun perayaan siklus kehidupan dalam budaya masyarakat Minangkabau dapat dilihat pada gambar 3. 
Serat Rupa Journal of Design, January 2021, Vol.5, No.1: 80 - 105

E-ISSN: 2477-586X, ISSN: 2338-3348 | https://doi.org/10.28932/srjd.v5i1.2984 | Received: 25- 09- 2020, Accepted: 17 -01 - 2021 Vania Dwi Amanda Surya, Gregorius Prasetyo Adhitama

Rumah Gadang : Ruang dan Budaya Makan dalam Siklus Hidup Masyarakat Minangkabau

\begin{tabular}{|c|c|c|c|c|c|c|}
\hline $\begin{array}{c}\text { Jenis } \\
\text { Kegiatan }\end{array}$ & $\begin{array}{l}\text { Tahapan } \\
\text { Siklus } \\
\text { Hidup } \\
\end{array}$ & $\begin{array}{c}\text { Nama } \\
\text { Kegiatan }\end{array}$ & $\begin{array}{l}\text { Orang yang } \\
\text { Berkegiatan }\end{array}$ & Bentuk Kegiatan & Proses Kegiatan & Lokasi Kegiatan \\
\hline \multirow{8}{*}{$\sum_{\substack{0\\
}}^{\vec{\pi}}$} & \multirow{3}{*}{ 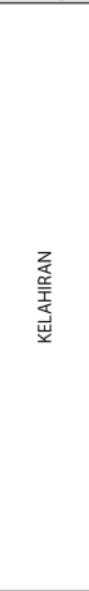 } & $\begin{array}{l}\text { Turun } \\
\text { Mandi }\end{array}$ & $\begin{array}{l}\text { 1. Bayi baru lahir } \\
\text { 2. Bapak (sumando) } \\
\text { 3. Keluarga bapak (induak } \\
\text { bako) } \\
\text { 4. Keluarga ibu (bundo } \\
\text { kanduang \& ninik mamak) } \\
\text { 5. Masyarakat sekitar } \\
\text { 6. Alim ulama }\end{array}$ & $\begin{array}{l}\text { Memandikan anak ke } \\
\text { sungai setelah berusia } 40 \\
\text { hari untuk diperlihatkan } \\
\text { kepada masyarakat ramai. }\end{array}$ & $\begin{array}{l}\rightarrow \text { Rombongan keluarga induak bako hadir } \\
\rightarrow \text { Jamuan makan bersama } \\
\rightarrow \text { Arak-arakan ke tepian sungai (tempat mandi) dan pembagian } \\
\text { makanan khas kepada masyarakat sekitar } \\
\rightarrow \text { Pemandian bayi dan sunatan bagi anak perempuan } \\
\rightarrow \text { Pembagian makanan khas untuk rombongan } \\
\rightarrow \text { Bayi'dirabun' dengan asap } \\
\rightarrow \text { Rombongan pulang } \\
\rightarrow \text { Nenek melakukan 'tagua' pada bayi sebelum masuk rumah } \\
\rightarrow \text { Pemberian minyak kepada bayi dan dirabun kembali } \\
\rightarrow \text { Nenek berkeliling rumah dengan bayi }\end{array}$ & Rumah ibu si bayi \\
\hline & & Aqiqah & $\begin{array}{l}\text { 1. Bayi baru lahir } \\
\text { 2. Bapak (sumando } \\
\text { 3. Keluarga bapak (induak } \\
\text { bako) } \\
\text { 4. Keluarga ibu (bundo } \\
\text { kanduang \& ninik mamak) } \\
\text { 5. Masyarakat sekitar } \\
\text { 6. Alim ulama }\end{array}$ & $\begin{array}{l}\text { Upacara adat sesuai sunah } \\
\text { Rasullah S.A.W, melakukan } \\
\text { penyembelihan hewan } \\
\text { qurban dan mengadakan } \\
\text { jamuan makan bersama. }\end{array}$ & $\begin{array}{l}\rightarrow \text { Prosesi pemotongan rambut bayi minimal } 7 \text { helai } \\
\rightarrow \text { Pemberian nama untuk bayi } \\
\rightarrow \text { Jamuan makan bersama } \\
\rightarrow \text { Pembacaan doa aqiqah } \\
\rightarrow \text { Pembayaran tahilan rambut oleh ayah si bayi. }\end{array}$ & Rumah ibu si bayi \\
\hline & & $\begin{array}{l}\text { Manjapuik } \\
\text { Jo Maanta } \\
\text { Anak }\end{array}$ & $\begin{array}{l}\text { 1. Anak bayi berumur } 3 \text { bulan } \\
\text { 2. Keluarga bapak (Induak } \\
\text { bako) } \\
\text { 3. Keluarga ibu (bundo } \\
\text { kanduang \& ninik mamak) }\end{array}$ & \begin{tabular}{|l|} 
Penjemputan dan \\
pengantaran kembali anak \\
oleh Induak Bako untuk \\
menginap di rumahnya \\
ketika anak telah berumur \\
3 bulan \\
\end{tabular} & $\begin{array}{l}\rightarrow \text { Induak bako datang menjemput bayi } \\
\rightarrow \text { Membawa bayi dengan menggunakan kain balapak dan } \\
\text { manik-manik ke rumahnya } \\
\rightarrow \text { Menginapkan bayi selama } 3 \text { hari di rumah Induak Bako } \\
\rightarrow \text { Induak Bako mengantarkan kembali bayi ke rumah ibunya }\end{array}$ & $\begin{array}{l}\text { Rumah ibu si anak } \\
\text { dan rumah Induak } \\
\text { Bako }\end{array}$ \\
\hline & 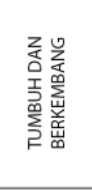 & Sunatan & $\begin{array}{l}\text { 1. Anak yang disunat } \\
\text { 2. Bapak (sumando) } \\
\text { 3. Keluarga bapak (Induak } \\
\text { bako) } \\
\text { 4. Keluarga ibu (bundo } \\
\text { kanduang \& ninik mamak) } \\
\text { 5. Masyarakat sekitar } \\
\text { 6. Alimulama }\end{array}$ & $\begin{array}{l}\text { Perayaan bagi anak-anak } \\
\text { laki-laki yang telah } \\
\text { melakukan sunatan }\end{array}$ & $\begin{array}{l}\rightarrow \text { Acara kesenian jika ada } \\
\rightarrow \text { Pembacaan doa } \\
\rightarrow \text { Jamuan makan bersama }\end{array}$ & Rumah ibu si anak \\
\hline & \multirow{3}{*}{ 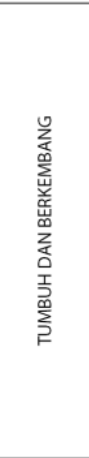 } & $\begin{array}{l}\text { Khatam } \\
\text { Quran }\end{array}$ & $\begin{array}{l}\text { 1. Anak yang Khatam Quran } \\
\text { 2. Guru mengaji } \\
\text { 3. Orang Tua }\end{array}$ & $\begin{array}{l}\text { Perayaan bagi anak-anak } \\
\text { yang telah menamatkan } \\
\text { kajinya/tamat Al-Quran } \\
\text { (telah tahu/ pandai } \\
\text { membaca Al-Quran) }\end{array}$ & $\begin{array}{l}\rightarrow \text { Jamuan makan bersama } \\
\rightarrow \text { Pembacaan Al-Quran oleh yang telah khatam Quran } \\
\rightarrow \text { Pembacaan doa } \\
\rightarrow \text { Pawai diringi kesenian Rabbana }\end{array}$ & Surau \\
\hline & & $\begin{array}{l}\text { Baralek } \\
\text { Pernikahan }\end{array}$ & $\begin{array}{l}\text { 1. Keluarga mempelai wanita } \\
\text { (Sumando, bundo kanduang } \\
\text { dan ninik mamak) } \\
\text { 2. Keluarga mempelai pria } \\
\text { 3. Masyarakat sekitar } \\
\text { 4. Alim ulama }\end{array}$ & $\begin{array}{l}\text { Acara pesta merayakan } \\
\text { pernikahan dua insan } \\
\text { manusia }\end{array}$ & $\begin{array}{l}\rightarrow \text { Manjapuik marapulai } \\
\rightarrow \text { Akad nikah } \\
\rightarrow \text { Basandiang (penganten disandingkan) } \\
\rightarrow \text { Pejamuan (Jamuan makan bersama) } \\
\rightarrow \text { Pembacaan doa }\end{array}$ & $\begin{array}{l}\text { Rumah mempelai } \\
\text { wanita }\end{array}$ \\
\hline & & $\begin{array}{l}\text { Batagak } \\
\text { Pangulu }\end{array}$ & $\begin{array}{l}\text { 1. Pangulu-pangulu yang } \\
\text { diangkat sumpah } \\
\text { 2. Pangulu-pangulu yang } \\
\text { terdahulu } \\
\text { 3. Alimulama } \\
\text { 4. Tamu dari pemerintahan }\end{array}$ & $\begin{array}{l}\text { Upacara pengambilan } \\
\text { sumpah janji dan } \\
\text { penobatan pangulu } \\
\text { diangkat sebagai } \\
\text { pemimpin kaum dengan } \\
\text { gelar Datuak }\end{array}$ & $\begin{array}{l}\rightarrow \text { Pemberitahuan pangulu yang akan diangkat } \\
\rightarrow \text { Pembacaan ayat suci Al-Quran } \\
\rightarrow \text { Mengenakan Deta (pakaian kebesaran penghulu) } \\
\rightarrow \text { Pengucapan sumpah janji } \\
\rightarrow \text { Pembacaan doa } \\
\rightarrow \text { Jamuan makan bersama } \\
\rightarrow \text { Arak-arakan pangulu ke rumah induk bakonya dari balai adat } \\
\text { diiringi kesenian tradisional }\end{array}$ & Balai adat \\
\hline & $\begin{array}{ll}K & \\
E & 1 \\
M & A \\
A & N \\
T & \end{array}$ & $\begin{array}{l}\text { Upacara } \\
\text { Kematian }\end{array}$ & $\begin{array}{l}\text { 1. Keluarga almarhum/ah } \\
\text { (bundo kanduang dan ninik } \\
\text { mamak) } \\
\text { 2. Keluarga induak bako } \\
\text { 3. Masyarakat sekitar } \\
\text { 4. Alim ulama }\end{array}$ & \begin{tabular}{|l|} 
Upacara ketika seseorang \\
meninggal dunia dengan \\
syariat Islam dengan \\
membaca doa (ayat suci AI- \\
Quran) pada malam ke-3,7, \\
dan 100 hari
\end{tabular} & $\begin{array}{l}\rightarrow \text { Pembacaan Al-Quran } \\
\rightarrow \text { Ceramah agama } \\
\rightarrow \text { Pembacaan doa } \\
\rightarrow \text { Jamuan makan }\end{array}$ & Rumah almarhum/ah \\
\hline \multirow{2}{*}{ 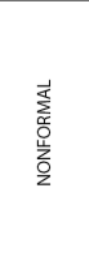 } & \multirow{2}{*}{ 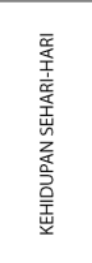 } & $\begin{array}{l}\text { Makan } \\
\text { Bersama } \\
\text { Keluarga }\end{array}$ & $\begin{array}{l}\text { 1. Bapak (Sumando) } \\
\text { 2. Ibu } \\
\text { 3. Anak-anak } \\
\text { 4. Anggota keluarga lainnya } \\
\text { (jika ada) }\end{array}$ & \begin{tabular}{|l|} 
Kegiatan makan bersama \\
keluarga, biasanya \\
dilakukan pada \\
pagi/malam hari bertujuan \\
untuk sarana komunikasi \\
\end{tabular} & $\begin{array}{l}\rightarrow \text { Sumando meminta makan bersama } \\
\rightarrow \text { Mamak memanggil anggota keluarga dan menyiapkan } \\
\text { makanan } \\
\rightarrow \text { Makan bersama } \\
\rightarrow \text { Nasihat oleh orang yang dituakan }\end{array}$ & Rumah keluarga \\
\hline & & $\begin{array}{l}\text { Menjamu } \\
\text { Tamu }\end{array}$ & $\begin{array}{l}\text { 1. Anggota keluarga } \\
\text { 2. Tamu }\end{array}$ & $\begin{array}{l}\text { Kegiatan makan bersama } \\
\text { yang dilakukan ketika } \\
\text { menjamu tamu sebagai } \\
\text { penghormatan }\end{array}$ & $\begin{array}{l}\rightarrow \text { Tamu datang } \\
\rightarrow \text { Berbincang-bincang } \\
\rightarrow \text { Para wanita di rumah menyiapkan makanan } \\
\rightarrow \text { Sumando mengajak tamu makan bersama } \\
\rightarrow \text { Makan bersama } \\
\rightarrow \text { Melanjutkan perbincangan }\end{array}$ & Rumah keluarga \\
\hline
\end{tabular}

Selain pada perayaan siklus kehidupan, kegiatan makan juga mengambil peran penting dalam kehidupan sehari-hari masyarakat Minangkabau. Kegiatan makan dilakukan bersama-sama di dalam keluarga sebagai bentuk sarana bertukar informasi tentang kehidupan masing-masing anggota. Selain itu, menjamu tamu juga merupakan sebuah keharusan, tata krama sopan santun dalam pergaulan masyarakat Minangkabau. Tabel 1 
menujukkan hubungan kegiatan makan sebagai bentuk perayaan siklus hidup masyarakat Minangkabau dan dalam menjalankan kehidupan sehari-hari berdasarkan adat istiadatnya.

\section{Rumah Gadang Bangunan Tradisional Minangkabau}

Menurut Amos Rapoport (1997) terdapat lima syarat yang harus dipenuhi dalam menentukan sebuah lingkungan efektif dalam memfasilitasi sebuah kegiatan. Syarat-syarat tersebut adalah (1) kesesuaian pengaturan sistem perilaku terhadap ruang, (2) kesesuaian definisi ruang sebagai aspek fisik ruang yang harus ada terhadap kegiatan, (3) kesesuaian dengan tata cara perilaku pada kegiatan, (4) aspek-aspek tersembunyi lainnya pada kegiatan, (5) relasi ruang terhadap lingkungan sekitarnya.

Suarman dkk (2000) menyatakan bahwa seperti namanya gadang yang artinya besar, rumah ini memiliki ukuran yang besar, bentuk yang khas, fungsi yang beragam, dan ukiran yang memiliki arti. Rumah gadang merupakan rumah panggung, memiliki bentuk persegi panjang, beratap gonjong dan beberapa memiliki anjuang di kanan dan kiri rumah. Bagian dalam terbagi menjadi ruang dan lanjar yang ditandai dengan tiang dengan beragam ukuran sesuai dengan kemampuan masing-masing suku. Lanjar paling belakang terdiri dari bilik-bilik yang merupakan kamar tidur. Pada bagian ruang dibagi lagi menjadi ujung dan pangkal, pangkal merupakan bagian yang terdekat dengan pintu masuk ke dalam rumah.

Pada lanjar di bagian depan rumah terdapat ruang terbuka yang disebut dengan ruang lepas yang biasanya digunakan saat perayaan upacara adat. Selain itu, ruang lepas terbagi menjadi dua area yang dipisahkan oleh kolom, dimana area setelah kolom di depan bilik biasanya digunakan untuk menjamu tamu. Penempatan penghuni dari bilik-bilik memiliki aturan yaitu paling ujung merupakan anggota keluarga paling muda dan semakin ke pangkal milik anggota keluarga yang tertua. Pada rumah gadang tertentu juga terdapat ruang dalam yang merupakan ruang menuju ke dapur. Pada area ini biasanya para wanita menyimpan makanan sebelum dihidangkan ketika dilakukan upacara adat dan kenduri di 
rumah gadang. Selain itu, di beberapa rumah juga memiliki serambi yaitu ruangan sebelum memasuki rumah. Tangga terhubung ke serambi dan dari serambi dapat ditemui akses pintu masuk menuju ke dalam rumah. Serambi merupakan perkembangan variasi dari berbagai jenis rumah Gadang. Di daerah lainnya, penamaan serambi digunakan untuk menyebut posisi tangga menuju ke dalam rumah. Berikut ini gambaran dari prinsip dasar rumah Gadang.
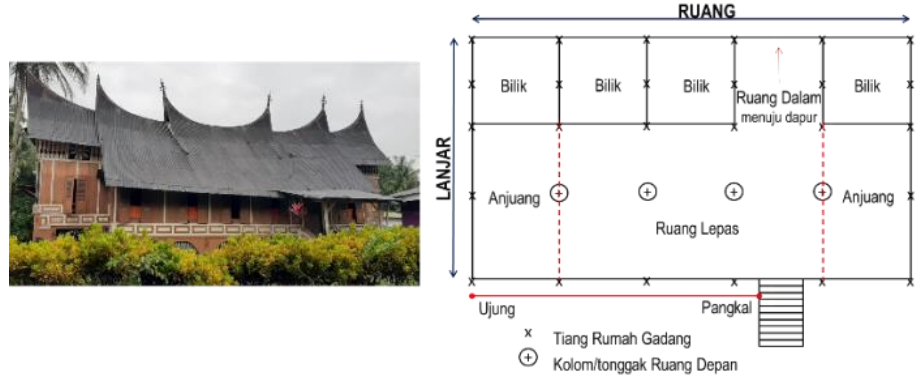

Gambar 4. Contoh rumah gadang dan prinsip dasar tata ruangnya Sumber: Dokumentasi pribadi, 20202 dan Suarman dkk, 2000

Dalam adat Minangkabau juga diatur tata krama di dalam rumah Gadang yang harus dipenuhi berdasarkan sistem kekerabatan matrilinieal, khususnya tata cara duduk. Tata cata duduk ini kemudian yang menjadi acuan ketika dilaksanakannya berbagai jenis upacara adat di Rumah Gadang. Gambar 5 ini menunjukkan aturan posisi tempat duduk di dalam Rumah Gadang. 

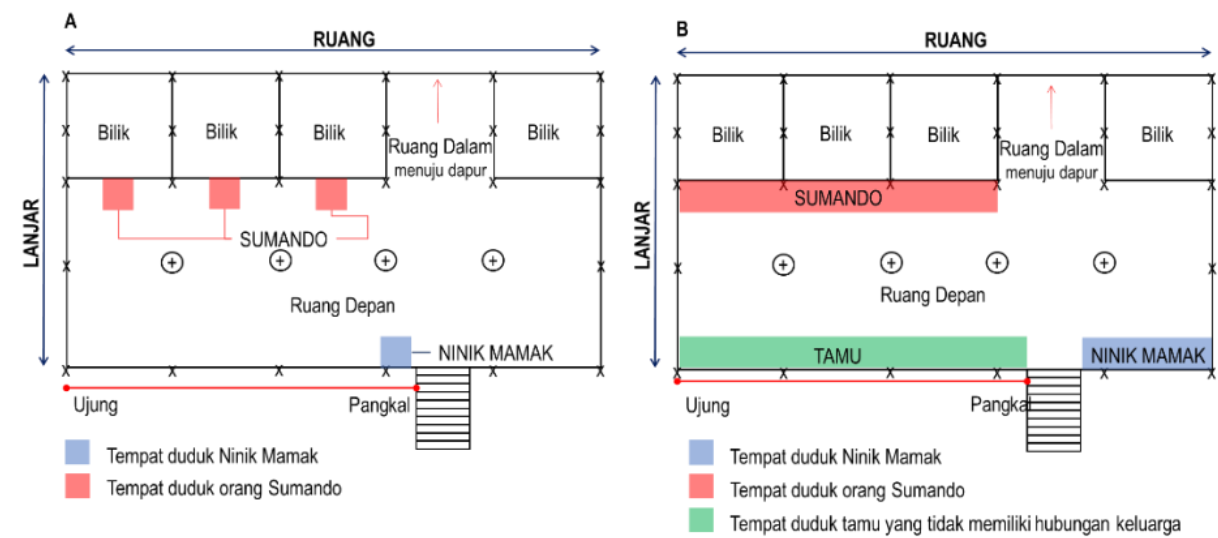

Gambar 5. Tata cara duduk sesuai adat sopan santun minangkabau di dalam rumah gadang Sumber: Suarman dkk, 2000

Adapun pedoman tata cara duduk di dalam rumah Gadang (Suarman dkk, 2000) adalah sebagai berikut. (1) Duduk beradat yaitu duduk bersila untuk laki-laki dan duduk bersimpuh untuk wanita. (2) Tempat duduk untuk mamak berada di pangkal mengarah ke bilik kemenakan. (3) Orang sumando harus duduk di depan kamarnya dan menghadap ke jendela depan. (4) Seseorang tidak boleh duduk dekat mamak atau laki-laki sesuku dengan isterinya. (5) Saat perjamuan, di sepanjang dinding bilik merupakan tempat duduk sumando. (6) Tamu-tamu yang tidak ada hubungan dengan pemilik rumah duduk di depan jendela sebelah kiri tangga terus ke ujung. (7) Saat perjamuan di pangkal sebelah kanan tangga merupakan tempat duduk ninik mamak dan pihak yang mengadakan acara. (8) Raja Janang (pelayan) yang bertugas ketika acara merupakan anak lelaki dari mamak di rumah itu.

\section{PEMBAHASAN}

Pada pembahasan ini akan dijabarkan terlebih dahulu hasil penelitian sesuai tahapan penelitian yang telah dijabarkan pada metode penelitian. Setelah itu dilanjutkan dengan diskusi dari hasil penelitian yang telah dijabarkan sebelumnya.

\section{Elemen Nonfisik pada Ruang dan Budaya Makan Minangkabau}


Tahap ini merupakan penjabaran penemuan elemen-elemen nonfisik budaya makan Minangkabau yaitu proses kegiatan makan, tata cara duduk, jenis makan, dan peran kegiatan makan (tabel 2). Adapun elemen-elemen ini berdasarkan aturan adat istiadat masyarakat Minangkabau yang cenderung lebih kompleks sehingga ruang dan peralatan yang digunakan juga lebih banyak (Mintosih dan Widiyanto, 1996). Selain itu, pada elemenelemen nonfisik ini juga ditemukan peran dan fungsi kegiatan makan sebagai kegiatan sosial (Newman, 2009 dan Maximillian 2013) sesuai dengan pepatah adat Minangkabau tentang kegiatan makan (Rekarti, 2003). Berdasarkan tabel 2, elemen-elemen non fisik pada kegiatan makan ketika Upacara Turun Mandi (K1) adalah sebagai berikut. (1) Wanita memiliki peran dalam proses memasak dan menyiapkan makanan, serta menyajikan makanan sebelum acara. (2) Pria bertanggung jawab dalam melaksanakan seluruh rangkaian acara termasuk jamuan makan (Ninik Mamak dan Sumando), dan menghidangkan makanan ketika acara berlangsung (Raja janang yang merupakan anak pisang). (3) Kegiatan makan dilakukan dengan duduk lesehan dengan alas kain seprah dan menggunakan tangan. (4) Makanan yang dihidangkan merupakan makanan adat yang harus ada dalam upacara adat yaitu olahan daging sapi/kerbau (rendang). (5) Jamuan makan merupakan sarana interaksi sosial antara pihak yang mengadakan acara dan tamu undangan, serta antar masing-masing anggota keluarga yaitu Bundo Kanduang, Ninik mamak, Sumando, dan anak-anak. 


\begin{tabular}{|c|c|c|c|c|c|}
\hline & \multirow{2}{*}{$\frac{\text { KELAHIRAN }}{\text { Turun Mandi (K1) }}$} & \multirow{2}{*}{$\begin{array}{l}\text { TUMBUH BERKEMBANG } \\
\text { Baralek Pernikahan (K2) }\end{array}$} & \multirow{2}{*}{$\frac{\text { KEMATIAN }}{\text { Mendoa (K3) }}$} & \multicolumn{2}{|c|}{ KEHIDUPAN SEHARI-HARI } \\
\hline & & & & Makan Bersama Keluarga (K4) & Menjamu Tamu (K5) \\
\hline Waktu & Awal acara & Akhir acara & Akhir Acara & Akhir Acara & Akhir acara \\
\hline $\begin{array}{l}\text { Orang yang } \\
\text { memasak }\end{array}$ & Para wanita di keluarga dibantu tetangga & Para wanita di keluarga dibantu tetangga & Para wanita di keluarga dibantu tetangga & Wanita di keluarga & Wanita di keluarga \\
\hline \multirow{2}{*}{$\begin{array}{l}\text { Orang yang } \\
\text { menyajikan }\end{array}$} & Sebelum makan: Wanita di keluarga & Sebelum makan: Wanita di keluarga & Sebelum makan: Wanita di keluarga & Sebelum makan: Wanita di keluarga & $\begin{array}{c}\text { Sebelum makan: Wanita } \\
\text { di keluarga }\end{array}$ \\
\hline & $\begin{array}{c}\text { Ketika makan: Raja Janang/Dubalang (anak } \\
\text { lelaki dari mamak) }\end{array}$ & $\begin{array}{c}\text { Ketika makan: Raja Janang/ Dubalang (anak } \\
\text { lelaki dari mamak) }\end{array}$ & $\begin{array}{l}\text { Ketika makan: Raja Janang/Dubalang } \\
\text { (anak lelaki dari mamak) }\end{array}$ & Ketika makan: Wanita di keluarga & $\begin{array}{l}\text { Ketika makan: Wanita di } \\
\text { keluarga }\end{array}$ \\
\hline $\begin{array}{l}\text { Orang yang } \\
\text { menyantap }\end{array}$ & $\begin{array}{c}\text { Sumando, Ninik Mamak, Lelaki di keluarga, } \\
\text { dan tamu undangan (seluruhnya lelaki, } \\
\text { setelah selesai baru bergantian dengan } \\
\text { wanita) }\end{array}$ & \begin{tabular}{|c|} 
Sumando, Ninik Mamak, Lelaki di keluarga, \\
dan tamu undangan (seluruhnya lelaki, \\
setelah selesai baru bergantian dengan \\
wanita)
\end{tabular} & $\begin{array}{l}\text { Sumando, Ninik Mamak, Lelaki di } \\
\text { keluarga, dan tamu undangan } \\
\text { (seluruhnya lelaki, setelah selesai baru } \\
\text { bergantian dengan wanita) }\end{array}$ & Anggota keluarga pemilik rumah & Pemilik rumah dan tamu \\
\hline Cara duduk & $\begin{array}{l}\text { Lesehan duduk di lantai dengan } \\
\text { menggunakan alas kain seprah }\end{array}$ & $\begin{array}{l}\text { Lesehan duduk di lantai dengan } \\
\text { menggunakan alas kain seprah }\end{array}$ & $\begin{array}{l}\text { Lesehan duduk di lantai dengan } \\
\text { menggunakan alas kain seprah }\end{array}$ & Meja makan & $\begin{array}{l}\text { Lesehan duduk di lantai } \\
\text { dengan menggunakan } \\
\text { alas kain seprah }\end{array}$ \\
\hline Caramakan & Menggunakan tangan & Menggunakan tangan & Menggunakan tangan & Menggunakan tangan & Menggunakan tangan \\
\hline $\begin{array}{l}\text { Makanan } \\
\text { utama }\end{array}$ & $\begin{array}{c}\text { Nasi, hidangan daging, juadah (makanan } \\
\text { adat berupa nasi kunyik, nasi kuliak putian, } \\
\text { kanji, dan pangek pisang) }\end{array}$ & $\begin{array}{c}\text { Nasi, hidangan daging, juadah (makanan } \\
\text { adat berupa nasi kunyik, nasi kuliak putian, } \\
\text { kanji, dan pangek pisang) }\end{array}$ & Kue-kue dan minumanteh & $\begin{array}{l}\text { Nasi dan hidangan lauk pauk lainnya } \\
\text { yang tersedia di rumah }\end{array}$ & $\begin{array}{c}\text { Nasi dan hidangan lauk } \\
\text { pauk lainnya yang } \\
\text { tersedia di rumah }\end{array}$ \\
\hline $\begin{array}{l}\text { Peran } \\
\text { kegiatan } \\
\text { makan }\end{array}$ & $\begin{array}{l}\text { 1. Interaksi sosial antara wanita di keluarga } \\
\text { dan tetangga ketika memasak. } \\
\text { 2. Interaksi sosial antara Sumando, Ninik } \\
\text { Mamak, Lelaki di keluarga, dan tamu } \\
\text { undangan ketika kegiatan makan } \\
\text { berlangsung }\end{array}$ & $\begin{array}{l}\text { 1. Interaksi sosial antara wanita di keluarga } \\
\text { dan tetangga ketika memasak. } \\
\text { 2. Interaksi sosial antara Sumando, Ninik } \\
\text { Mamak, Lelaki di keluarga, dan tamu } \\
\text { undangan ketika kegiatan makan } \\
\text { berlangsung }\end{array}$ & $\begin{array}{l}\text { 1. Interaksi sosial antara wanita di } \\
\text { keluarga dan tetangga ketika memasak. } \\
\text { 2. Interaksi sosial antara Sumando, Ninik } \\
\text { Mamak Lelaki di keluarga, dan tamu } \\
\text { undangan ketika kegiatan makan } \\
\text { berlangsung }\end{array}$ & $\begin{array}{l}\text { 1. Interaksi sosial antar wanita di dalam } \\
\text { keluarga ketika memasak. } \\
\text { 2. Interaksi sosial antara orang tua dan/ } \\
\text { yang dituakan dengan anak-kemenakan } \\
\text { ketika berlangsungnya makan bersama }\end{array}$ & $\begin{array}{l}\text { 1. Interaksi sosial antar } \\
\text { wanita di dalam keluarga } \\
\text { ketika memasak. } \\
\text { 2. Interaksi sosial antara } \\
\text { pemilik rumah dan tamu } \\
\text { dalam jamuan makan }\end{array}$ \\
\hline
\end{tabular}

Pada elemen-elemen nonfisik ketika Upacara Baralek Pernikahan (K2) sama dengan dengan Upacara Turun Mandi (K1). Upacara Mendoa (K3) memiliki sedikit perbedaan dengan kedua upacara sebelumnya K1 dan K2. Perbedaannya adalah jenis makanan yang dihidangkan hanya kue-kue dan minuman berupa teh manis. Hal ini karena pada upacara mendoa (K3) merupakan kegiatan yang memperingati kematian, bukan sebuah berita baik seperti pada K1 dan K2. Di kehidupan sehari-hari, hasil elemen-elemen non fisik pada makan bersama keluarga (K4) adalah sebagai berikut. (1) Peran wanita sangat dominan dalam keseluruhan tahapan proses kegiatan makan yaitu memasak, menyajikan makanan, dan ikut serta menyantap makanan bersama. (2) Pria sebagai kepala keluarga berperan dalam memimpin dan memulai kegiatan makan. (3 )Kegiatan makan dilakukan menggunakan meja dan kursi makan dan menggunakan tangan. (4) Tidak ada makanan khusus, hanya makanan yang telah disiapkan sebelumnya. (5) Jamuan makan sebagai sarana interaksi sosial antara anggota keluarga yaitu orang tua dan anak-anak. Pada kegiatan makan ketika menjamu tamu (K5) terdapat dua perbedaan dibandingkan dengan makan bersama keluarga (K4) yaitu sebagai berikut. (1) Kegiatan makan dilakukan lesehan di depan bilik dari yang menerima tamu, duduk lesehan beralaskan kain seprah dan menggunakan tangan. (2) 
Jamuan makan merupakan sarana interaksi sosial antara pemilik rumah dan tamu.

\section{Elemen Fisik dan Data Space Syntax pada Ruang dan Budaya Makan Minangkabau}

Rumah Gadang Istano Rajo Alam Daulat Tuanku Disambah ini memiliki persegi panjang dengan dua anjuang di ujung dengan dua level ketinggian lantai dan satu anjuang di pangkal rumah, dimana bagian ini merupakan bangunan utama. Selain itu terdapat bangunan tambahan terletak di belakang yang terhubung melalui ruang dalam. Bangunan tambahan ini berfungsi sebagai ruang makan, dapur, dan toilet. Berikut ini gambaran dari Rumah Gadang Istano Rajo Alam Tuanku Disambah.

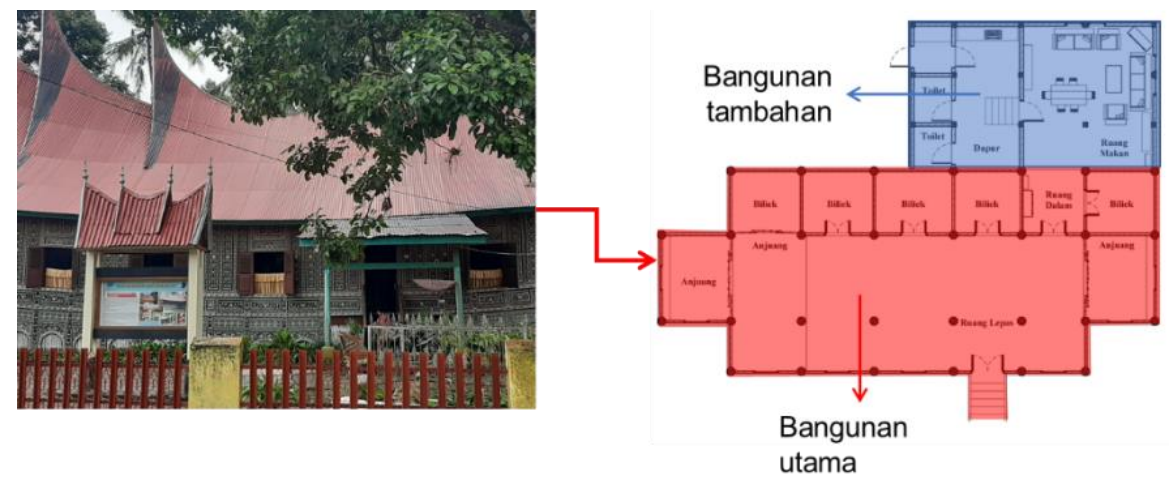

Gambar 6. Denah bangunan dan potret Rumah Gadang Istano Rajo Alam Tuanku DisambahTata Sumber: Dokumentasi dan ilustrasi pribadi, 2020

Penjabaran hasil pada tahap 2 dan 3 dilakukan bersamaan berdasarkan perayaan siklus hidup dan dalam kehidupan sehari-hari. Elemen fisik meliputi tata ruang ketika acara berlangsung, sirkulasi pada proses kegiatan makan, pengaturan dan arah posisi tempat duduk, dan tata letak makanan. Hasil data pada tahap 2 digunakan sebagai dasar analisis tahap 3 dengan menggunakan teknik space syntax yaitu convex space dan j-graph ketika kegiatan makan berlangsung untuk mendapatkan data nilai konektivitas dan integrasinya.

\section{Upacara Turun Mandi (K1)}

Berdasarkan gambar 7 terdapat beberapa penemuan penting terkait hubungan ruang dan budaya makan masyarakat Minangkabau. (1) Ruang lepas dan anjuang pertama di ujung 
rumah pada bangunan utama digunakan sebagai area persajian dan penyantapan. (2) Tahapan memasak dan menyiapkan makanan dilakukan di bangunan tambahan yang terletak di bagian belakang. (3) Anjuang di pangkal rumah digunakan sebagai area peletakan bayi. (4) Ruang dalam sebagai area penyimpanan merupakan ruang penghubung dan sirkulasi dari area persiapan menuju area persajian dan persantapan. (5) Luasan area persiapan lebih besar dari pada area penyantapan, sedangkan area penyimpanan lebih kecil dari kedua area tersebut. (6) Pada area penyantapan terbentuk kelompok ruang sesuai dengan aturan posisi duduk di rumah Gadang yang ditandai oleh posisi dinding, kolom, dan kain seprah alas makan serta adanya dan perbedaan ketinggian lantai di anjuang (Suarman dkk, 2020). Pada gambar 7 ini merupakan hasil data tahap 2 pada upacara Turun Mandi (K1) serta hasil perhitungan pada tahap 3. 


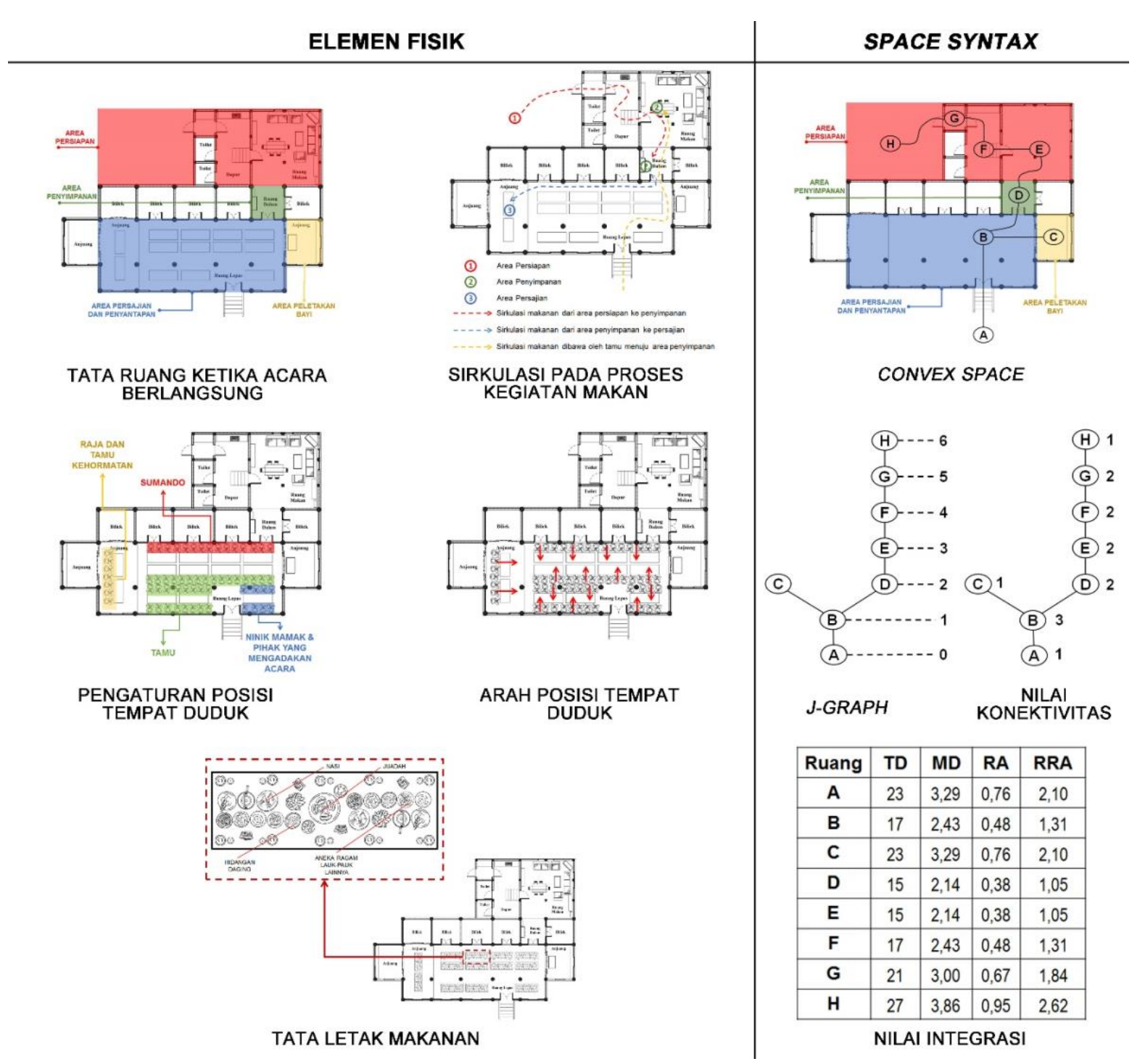

Gambar 7. Elemen-elemen fisik dan hasil perhitungan space syntax pada upacara turun mandi Sumber: Ilustrasi pribadi, 2020

Dari data tersebut, hasil perhitungan nilai konektivitas dan integrasinya Upacara Turun Mandi (K1) sebagai berikut. (1) Nilai konektivitas tertinggi adalah ruang B yang terhubung langsung dengan tiga ruang lainnya yaitu ruang lepas tempat penyajian dan penyantapan makanan. (2) Ruang $\mathrm{A}, \mathrm{C}$, dan $\mathrm{H}$ yang merupakan ruang terbuka di bagian depan akses menuju ke rumah, anjuang tempat peletakan bayi, dan ruang terbuka di belakang rumah tempat menyiapkan makanan, merupakan ruang-ruang yang memiliki nilai konektivitas 
terendah. (3) Ruang D yaitu ruang dalam area penyimpanan dan ruang E merupakan ruang makan area persiapan adalah ruang-ruang yang memiliki nilai integrasi tertinggi. (4) Nilai integrasi terendah adalah ruang $\mathrm{H}$ kemudian terendah kedua adalah ruang $\mathrm{A}$ dan $\mathrm{C}$ dengan nilai yang sama.

\section{Upacara Baralek Pernikahan}

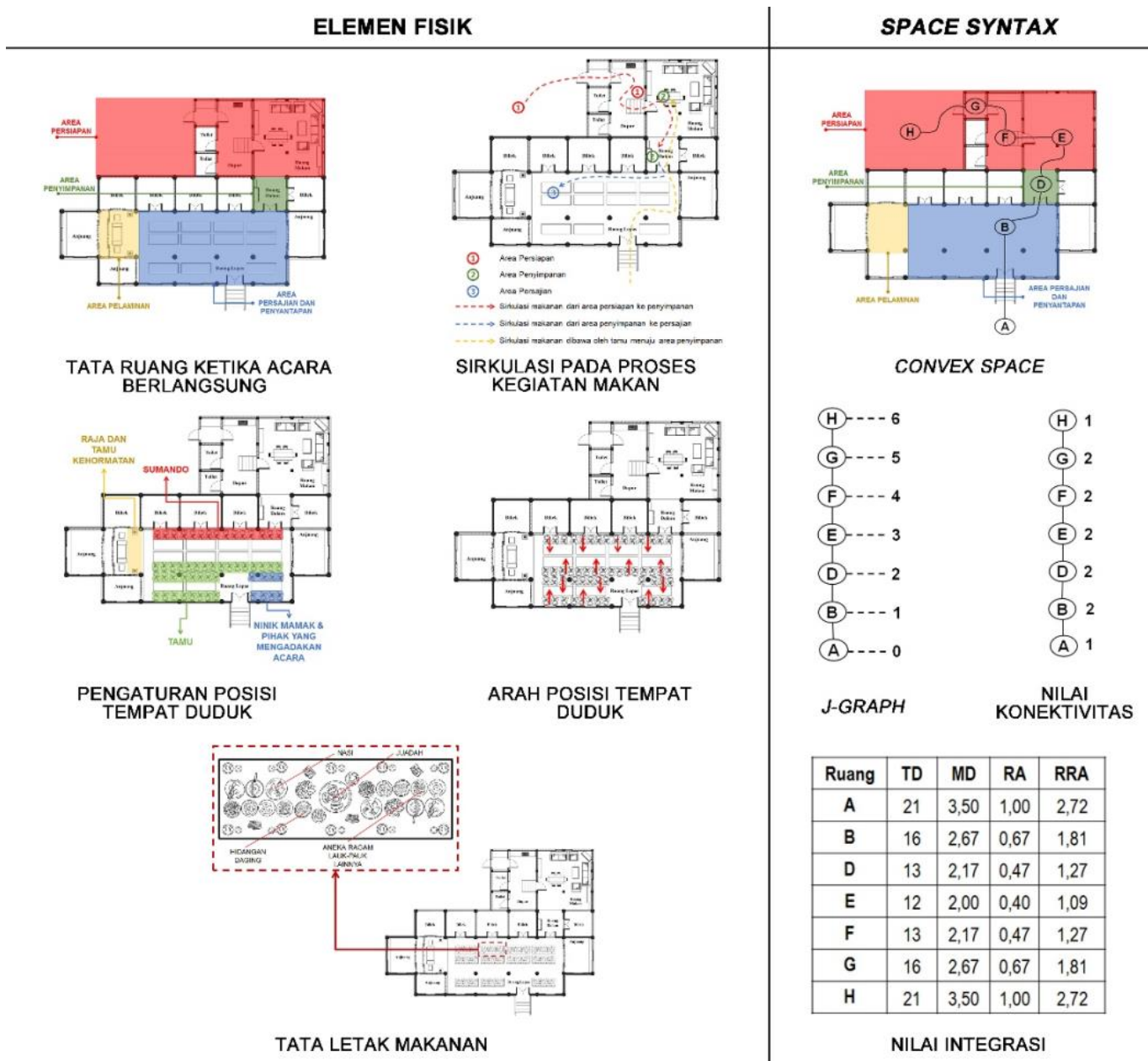

Gambar 8. Elemen-elemen fisik dan hasil perhitungan space syntax pada upacara baralek pernikahan Sumber: llustrasi pribadi, 2020

Berdasarkan gambar 8, temuan-temuan penting terkait hubungan ruang dan budaya makan masyarakat Minangkabau pada upacara Baralek Pernikahan (K2) tidak berbeda 
dengan jamuan makan pada upacara Turun Mandi (K1). Perbedaannya adalah (1) penggunaan anjuang hanya satu yaitu anjuang pertama di ujung rumah sebagai tempat pelaminan dari pengantin. (2) Walaupun demikian, anjuang ini tetap digunakan ketika jamuan makan berlangsung sebagai tempat duduk Raja dan tamu penting lainnya, karena ketika jamuan makan ini kedua mempelai belum boleh duduk di pelaminan.

Terdapat dua hasil perhitungan nilai konektivitas pada K2 yaitu sebagai berikut. (1) Ruang A (ruang terbuka akses menuju rumah) dan ruang $\mathrm{H}$ (ruang terbuka di belakang rumah) memiliki nilai konektivitas terendah dan terhubung dengan hanya satu ruang. (2) Nilai konektivitas tertinggi, terhubung dengan dua ruang lainnya adalah ruang B merupakan ruang lepas area persantapan, ruang D merupakan ruang dalam area penyimpanan, ruang E, F, G merupakan area persiapan. (3) Ruang E yaitu ruang dalam memiliki nilai integraso tertinggi dan tepat berada di tengah-tengah sistem. (4) Nilai integrasi terendah dimiliki ruang $\mathrm{A}$ dan $\mathrm{H}$, sama seperti pada $\mathrm{K} 1$.

\section{Upacara Mendoa}




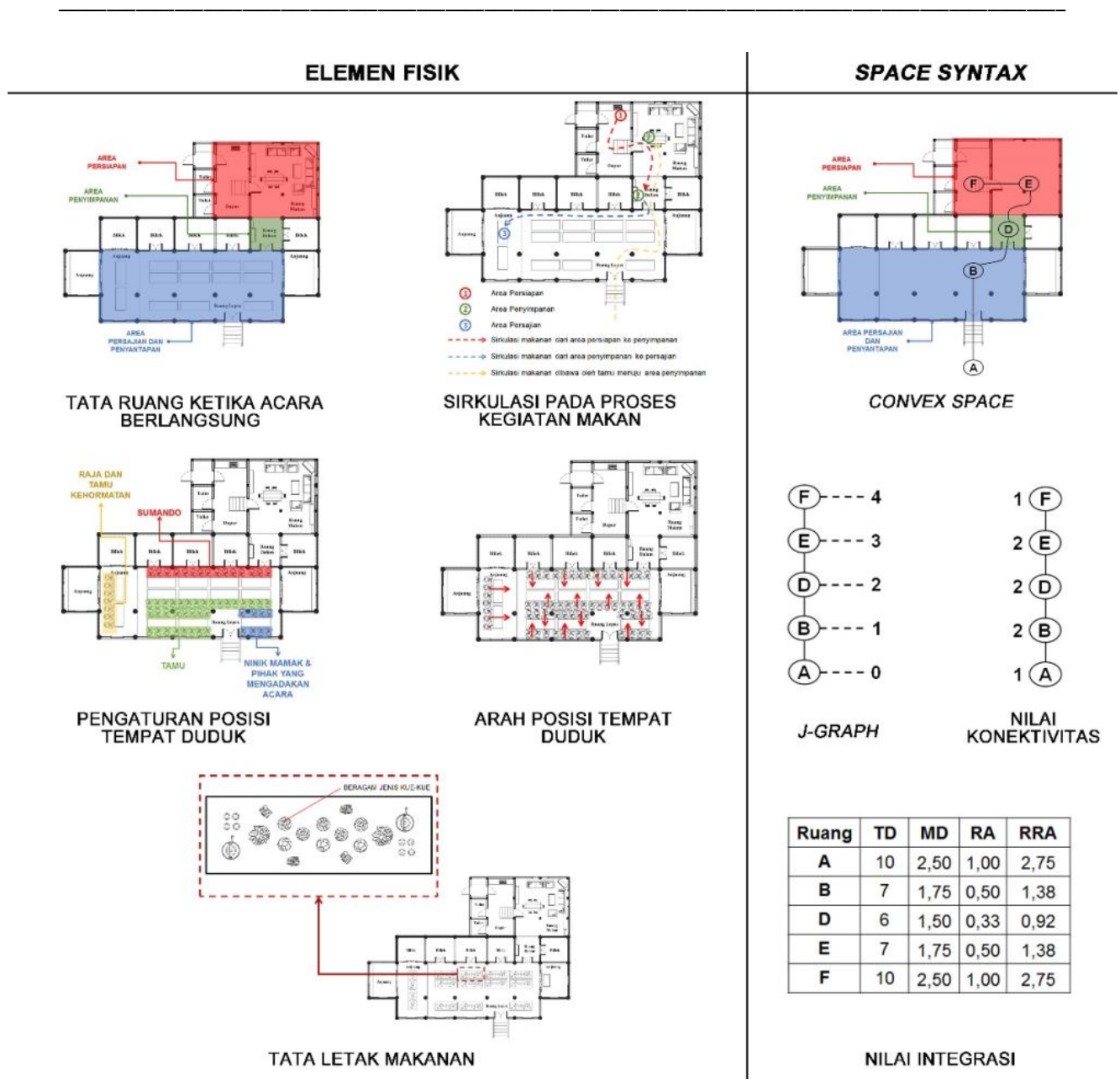

Gambar 9. Elemen-elemen fisik dan hasil perhitungan space syntax pada upacara mendoa Sumber: llustrasi pribadi, 2020

pada upacara Mendoa - K3 (lihat gambar 9) tidak terlalu berbeda dengan jamuan makan pada kedua upacara sebelumnya. Perbedaannya adalah (1) Anjuang yang digunakan hanya satu seperti pada upacara K2 dan hanya digunakan sebagai tempat duduk Raja dan tamu penting lainnya. (2) Pada area persiapan terdapat pengurangan jumlah ruang yang digunakan karena makanan yang dihidangkan lebih sederhana hanya kue-kue dan minuman teh.

Dari data tersebut, berikut ini beberapa hasil yang ditemukan. (1) Ruang yang memiliki nilai konektivitas tertinggi adalah ruang B, D, dan E sama seperti pada K2. (2) Nilai integrasi tertinggi dimiliki ruang $D$, ruang dalam area penyimpanan yang tepat berada di tengah 
sistem. (3) Nilai konektivitas terendah dimiliki ruang A dan F yang berubah menjadi di pinggir sistem yaitu ruang terbuka akses menuju rumah dan dapur area persiapan.

\section{Kehidupan Sehari-hari}

Adapun temuan-temuan penting pada makan bersama keluarga - K4 (lihat gambar 10) adalah sebagai berikut. (1) Dapur merupakan area persiapan dan ruang makan sebagai area penyajian dan penyantapan juga area penyimpanan. Ruang makan pada K4 ini merupakan area persiapan pada K1, K2, dan K3. (2) Luasan area persiapan lebih kecil dari area penyantapan karena kegiatan makan hanya untuk anggota keluarga. (3) Kegiatan makan dilakukan dengan menggunakan meja dan kursi sehingga posisi tempat duduk cenderung menempatkan orang yang dituakan di ujung meja makan (Surya dan Gabe, 2015).

Hasil penemuan ketika menjamu tamu (K5) sedikit berbeda dengan K4 dan memiliki beberapa kesamaan dengan K1, K2, dan K3. (1) Dapur tetap digunakan sebagai area persiapan, ruang makan beralih fungsi menjadi area penyimpanan, dan area penyajian dan penyantapan menggunakan ruang lepas. (2) Luasan area persiapan dan penyimpanan lebih besar dari pada area penyajian berbeda dengan ketika perayaan siklus hidup karena hanya sebagian area di ruang lepas yang digunakan dan orang yang mengikuti kegiatan makan lebih sedikit. (3) Kegiatan makan dilakukan lesehan dengan menggunakan kain seprah di depan kamar tidur (bilik) dari orang yang menerima tamu dan menggunakan tangan (5) Posisi tempat duduk sesuai dengan aturan sopan santun di rumah Gadang (Suarman dkk, 2000) yaitu sumando (pemilik rumah) duduk membelakangi dinding bilik dan tamu duduk di seberang sumando. 


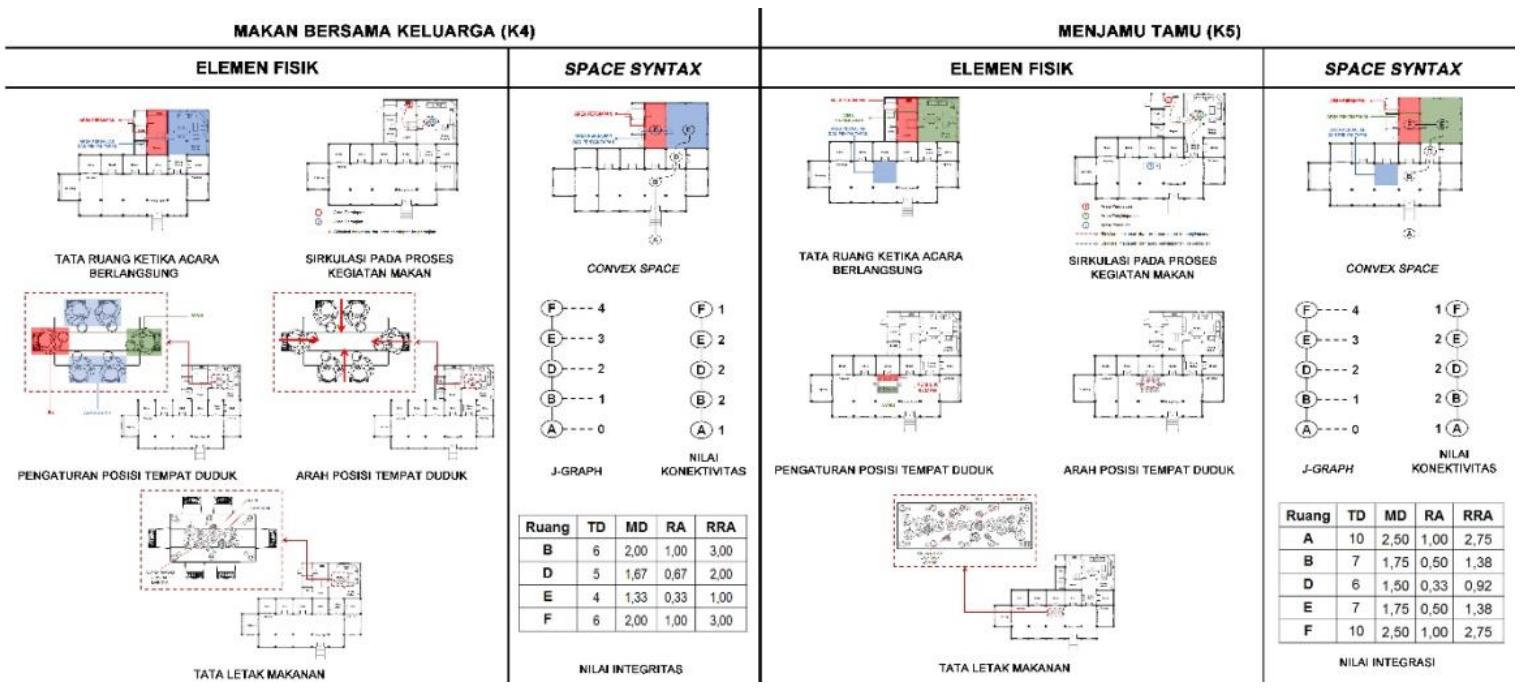

Gambar 10. Elemen-elemen fisik dan hasil perhitungan space syntax pada pada kehidupan sehari-hari ketika makan bersama keluarga dan menjamu tamu

Sumber: Ilustrasi pribadi, 2020

Pada kegiatan makan bersama keluarga terjadi kembali pengurangan ruang, adapun hasil tahap 3 adalah sebagai berikut. (1) Nilai konektivitas tertinggi adalah ruang D dan E yang berada di tengah sistem dan terhubung dengan dua ruang lainnya. (2) Nilai konektivitas terendah adalah ruang $\mathrm{B}$ dan $\mathrm{F}$ yang berada di pinggir sistem yang terhubung hanya dengan satu ruang lainnya, sekaligus juga memiliki nilai integrasi terendah. (3) Nilai integrasi tertinggi adalah ruang $\mathrm{E}$ merupakan ruang makan tempat berlangsungnya kegiatan menyantap makanan. Hasil nilai konektivitas dan integrasi pada kegiatan makan menjamu tamu tidak memiliki perbedaan dengan K3 karena (1) ruang yang digunakan sama namun memiliki perbedaan fungsi. (2) Fungsi ruang D dengan nilai integrasi tertinggi hanya sebagai ruang sirkulasi dari area penyimpanan (ruang E) menuju area penyantapan (ruang B).

\section{Diskusi Hasil Penelitian}

Hasil dari analisis elemen nonfisik, bagian ruang, dan elemen fisik, serta space syntax terhadap ruang dan budaya makan ditemukan bahwa terdapat pembagian area pada ruang-ruang di rumah Gadang berdasarkan proses kegiatan makan. Pada area penyantapan menunjukkan temuan yang paling khusus tentang aturan posisi tempat 
duduk ketika makan sesuai dengan tata sopan santun di dalam rumah Gadang (Suarman dkk, 2020). Setiap area pada tahapan proses kegiatan makan ditemukan berfungsi sebagai ruang sosial dengan peran berbeda-beda. Hasilnya juga memenuhi syarat lingkungan efektif yang dikemukakan oleh Rapoport (1977).

\section{Pembagian ruang dalam proses kegiatan makan}

Ruang-ruang di rumah Gadang terbagi sesuai dengan proses kegiatan makan dalam siklus hidup masyarakat Minangkabau yaitu area persiapan, area penyimpanan, dan area penyajian dan penyantapan. Pembagian ruang ini juga didasari oleh pembagian peran antara wanita dan pria dalam melaksanakan proses berlangsungnya kegiatan makan pada siklus hidup mereka (lihat gambar 11). Wanita berperan penting pada proses menyiapkan makanan melakukan kegiatan memasak di ruang-ruang pada bangunan tambahan di bagian belakang rumah, sebagaimana wanita Minangkabau yang bertugas mengasihi dan mengayomi keluarganya (Suarman dkk, 2000). Area persiapan yaitu ruang terbuka di belakang rumah $(\mathrm{H})$ pada $\mathrm{K} 1$ dan $\mathrm{K} 2$ dan ruang dapur $(\mathrm{F})$ pada $\mathrm{K} 3$, K4, dan $\mathrm{K} 5$ memiliki nilai j- graph terendah 3 dan tertinggi 6. Selain itu, juga memiliki nilai integrasi semakin rendah. Posisi ruang-ruang ini dimulai dekat dari tengah sistem dan menuju pinggir sistem (Siregar, 2014). Selain itu, posisinya yang terletak di bangunan tambahan pada bagian belakang rumah menyebabkan ruang-ruang ini berada di akhir sistem. Artinya ruang-ruang di area persiapan memilki tingkat aksesibilitas yang rendah dan tingkat privasi yang tinggi karena sulit dijangkau dan harus melewati ruang-ruang sebelumnya. Hal ini sebagaimana peran wanita dalam mengayomi keluarganya juga memiliki hak untuk dijaga dan diistemewakan, sehingga ruang-ruang yang digunakan oleh wanita Minangkabau harus dapat menjaga privasi mereka. 

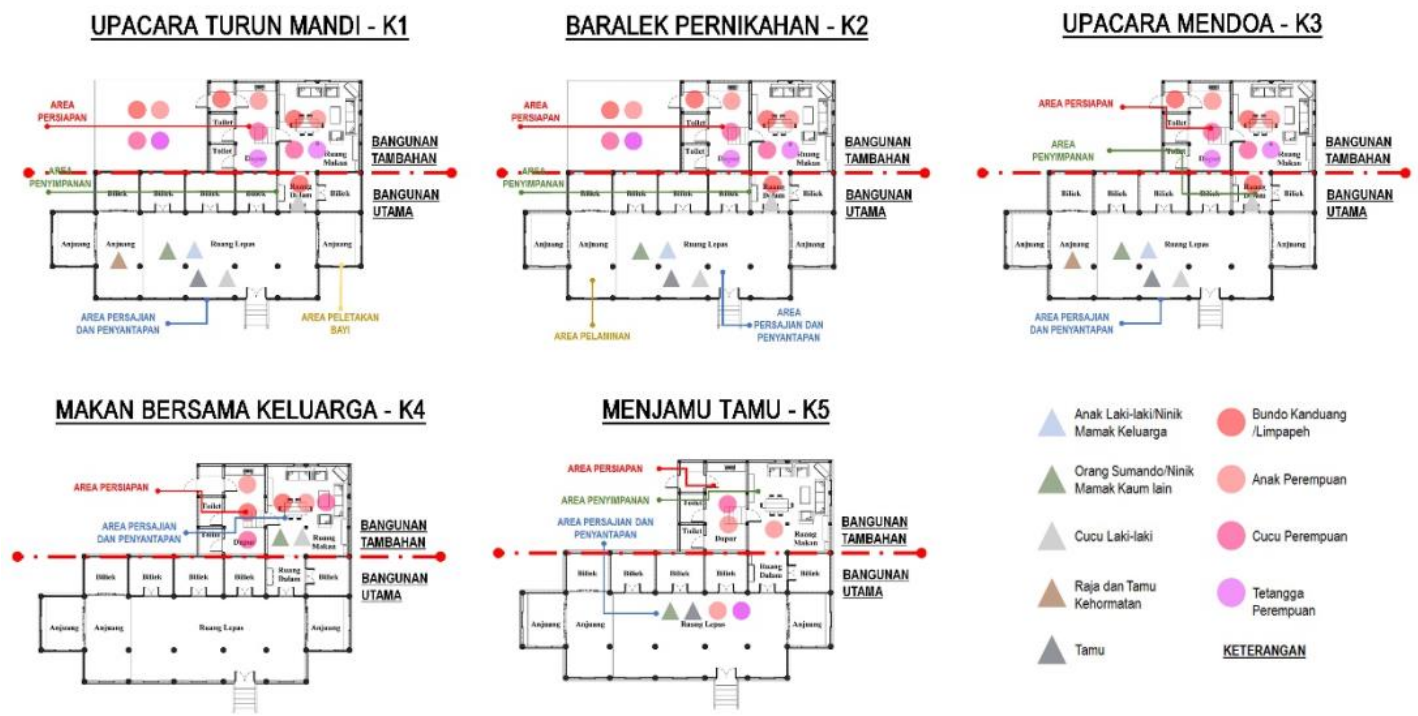

Gambar 11. Pembagian ruang berdasarkan peran wanita dan pria ketika proses kegiatan makan dan jenis bangunan pada rumah gadang

Sumber: Ilustrasi pribadi, 2020

Area penyimpanan pada K1, K2, dan K3 terletak di ruang dalam sedangkan pada K4 dan K5 menggunakan ruang makan. Berdasarkan nilai j-graph, kedua ruang ini memiliki nilai yang kecil yaitu 2. Sementara itu, pada nilai integrasi memiliki hasil nilai yang cukup tinggi dengan nilai RRA paling rendah pada $\mathrm{K} 1$ dan $\mathrm{K} 3$, serta nilai RRA terendah kedua pada K3, K4,dan K5. Ruang dalam sebagai area penyimpanan ini terletak tepat di tengah dan dekat dengan pusat sistem (Siregar, 2014). Artinya ruang ini dapat dengan mudah diakses dari ruang-ruang lainnya yang menjadi ruang sirkulasi dan penghubung dengan ruang-ruang lainnya dalam sistem. Pada konteks ruang dan budaya makan ini, ruang ini menghubungkan area persiapan dan area penyantapan dan sebagai penghubung antara wanita pemilik rumah (induak bako) dan raja janang atau anak lelaki (anak pisang). Hal ini dikarenakan sebagai area penyimpanan hanya dapat diakses oleh wanita pemilik rumah (induak bako) dan raja janang atau anak lelaki (anak pisang). Karena raja janang atau anak lelaki (anak pisang) yang menghidangkan makanan yang telah disiapkan oleh wanita pemilik rumah (induak bako) ketika sedang berlangsungnya kegiatan makan.

Lain halnya pada proses penyantapan pada perayaan siklus hidup yang dilakukan di ruang 
lepas dan anjuang di bagian depan rumah pada bangunan utama. Berdasarkan nilai $j$-graph kedua ruang ini menjadi satu bagian dan memiliki nilai 1. Sementara itu, nilai integrasinya cukup rendah dengan nilai RRA tertinggi kedua. Artinya ruang ini terletak juga di pinggir sistem (Siregar, 2014) namun pada bagian awal karena posisinya di bagian depan dan merupakan ruang pertama dan kedua yang langsung dapat diakses dari pintu masuk ke dalam rumah. Namun, pada kehidupan sehari hari ketika kegiatan makan bersama yang dilakukan di ruang makan dan menjamu tamu di sebagian area ruang lepas, wanita juga ikut serta dalam menyantap makanan. Hal ini sesuai dengan peran pria dalam proses kegiatan makan yaitu berperan penting dan bertanggung jawab dalam menjamu tamu ketika acara berlangsung. Karena dalam aturan adat Minangkabau, pria memiliki tanggung jawab yang besar dalam memelihara keluarganya (Suarman dkk, 2000) yang artinya ikut berperan aktif dalam kegiatan urusan keluarga.

Secara keseluruhan tugas wanita dan pria dalam masyarakat Minangkabau diatur berdasarkan sistem kekerabatan matrilinieal, garis keturunan ibu (Suarman dkk, 2000, Surya dan Gabe, 2015), yang terlihat jelas pada pembagian ruang berdasarkan proses pelaksanaan kegiatannya. Ruang-ruang di dalam rumah Gadang pada pelaksanaan kegiatan makan memenuhi salah satu syarat efektif sebuah lingkungan yaitu sesuai dengan "a behavior setting system" yang dikemukakan oleh Rapoport (1997). Ruang-ruang di dalam rumah Gadang ditata sesuai dengan aturan adat istiadat yang berlaku di dalam masyarakat Minangkabau. Penataan ruang dilakukan berdasarkan peran wanita dan pria dalam kehidupan berkeluraga dan bermasyarakat, termasuk dalam menjalankan budaya makannya.

\section{Tata cara duduk ketika makan}

Pada area penyantapan di ruang lepas terdapat tata aturan posisi tempat duduk yang diatur dalam tata sopan santun di dalam rumah Gadang (Suarman dkk, 2000). Pengaturan 
posisi tempat duduk ini membagi ruang lepas dalam beberapa kelompok sesuai dengan pengelompokkan pria di keluarga berdasarkan garis keturunan matrilinieal di Minangkabau (lihat gambar 12). Pengelompokkan ruang ini ditandai oleh elemen fisik dinding, kolom, dan kain seprah alas makanan serta perbedaan ketinggian lantai. Namun, hasil data dengan analisis space syntax pada nilai konektivitas dan integrasi belum dapat menggambarkan terjadinya kelompok-kelompok ruang pada area penyantapan ini. Aturan posisi tempat duduk ini hanya berlaku pada kegiatan makan K1, K2, K3, dan K5 yang menggunakan ruang lepas sebagai area penyantapan dengan duduk lesehan di lantai. Pada K4 yang melaksanakan kegiatan menyantap makanan di ruang makan dengan menggunakan meja dan kursi hanya memiliki kecenderungan menempatkan orang yang dituakan di ujung meja makan (gambar 11). Kecenderungan ini juga didasarkan pada aturan adat Minangkabau untuk menghormati orang yang dituakan sehingga biasanya diposisikan di bagian ujung meja makan (Surya dan Gabe, 2015).

Kegiatan makan ketika perayaan siklus hidup tata aturan posisi tempat duduk ini tidak memiliki perbedaan sama sekali. Ninik mamak duduk di bagian pangkal dekat dengan pintu rumah bersandar ke dinding halaman yang mengarah ke bilik kemanakan. Sumando harus duduk di depan biliknya membelakangi dinding kamar dan menghadap ke jendela. Tamu yang tidak ada hubungannya dengan keluarga yang mengadakan perayaan tidak boleh duduk dekat dengan ninik mamak. Anak lelaki yang merupakan kemenakan dari ninik mamak dan raja janang anak lelaki dari ninik mamak dapat duduk di depan dan menghadap ke ninik mamak. Aturan ini juga berlaku ketika menjamu tamu yaitu sumando tetap harus duduk di depan biliknya dan tamu duduk di hadapannya. 

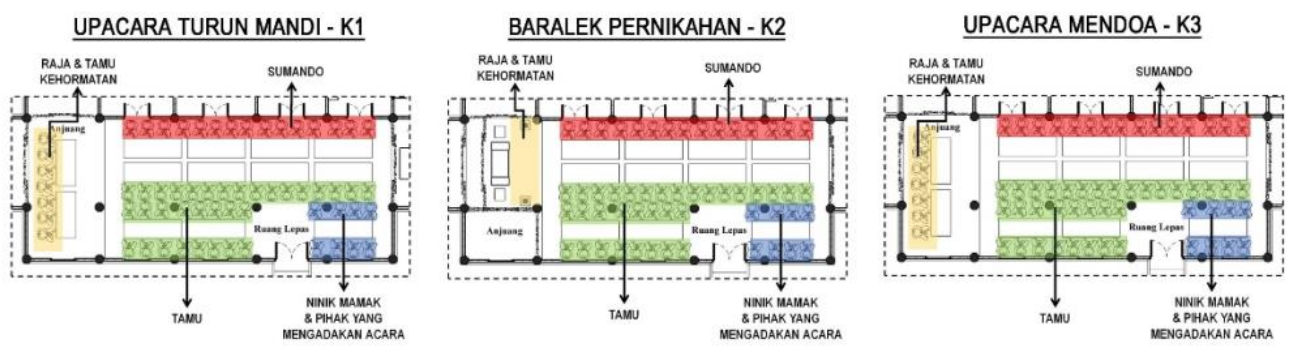

MAKAN BERSAMA KELUARGA - K4

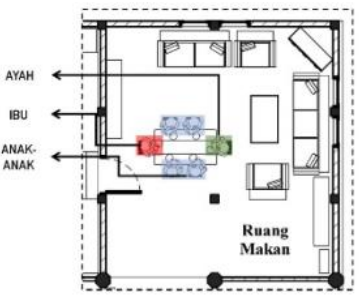

MENJAMU TAMU - K5
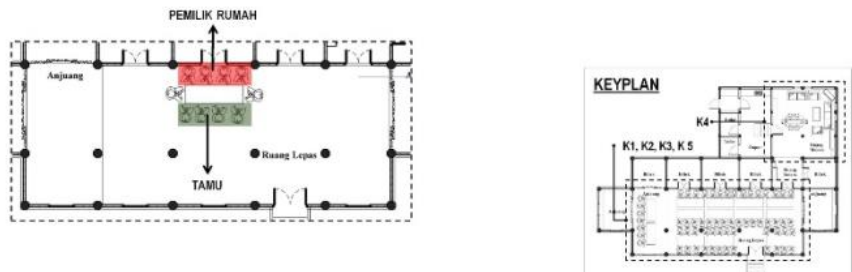

Gambar 12. Pengaturan posisi tempat duduk pada kegiatan makan ketika perayaan siklus hidup dan kehidupan sehari-hari

Sumber: Ilustrasi pribadi, 2020

Dalam aturan hubungan sistem garis keturunan ibu, ninik mamak dapat menjadi datuak kepala suku dari keluarga yang juga bertanggung jawab meningkatkan kesejahteraan serta menjaga kerukunan dan ketentraman (Suarman dkk, 2000). Posisi tempat duduk ninik mamak dapat melihat seluruh kondisi di dalam rumah dan menjaga pintu masuk. Tujuannya adalah untuk dapat memenuhi peran ninik mamak dalam mengawasi sumando dan mengajari kemenakan serta menjaga kerukunan keluarga. Sumando merupakan tamu di dalam keluarga dan tidak memiliki tanggung jawab di dalam keluarga istrinya tetapi diminta untuk ikut berperan aktif dalam permasalahan kaum (Suarman dkk, 2000). Oleh karena itu sumando duduk berada di depan biliknya dan menghadap ke pintu masuk rumah, jika sumando bermasalah harus menghadapi ninik mamak yang menjaga keluarga. Anak-anak lelaki duduk dihadapan ninik mamak untuk mendapatkan nasihat-nasihat dan belajar mengenai urusan keluarga.

Pada rumah Gadang lainnya, anjuang digunakan untuk tempat duduk tamu kehormatan. Namun, di rumah Gadang Istano Rajo Tuanku Alam Disambah ini, anjuang khusus dapat digunakan hanya ketika raja dan ratu hadir dalam perayaan dan sebagai tempat pelaminan 
pernikahan anak-anaknya. Berdasarkan hasil wawancara, adapun raja dan ratu ditempatkan di anjuang yang posisinya satu tingkat lebih tinggi dari ruang lepas, sebagaimana raja dan ratu yang memiliki tugas untuk bertanggung jawab pada kaumnya dan membawahi kepala-kepala suku. Peran besar raja dan ratu inilah yang menyebabkan mereka dikhususkan duduk di anjuang pada rumah Gadang untuk dapat mengawasi seluruh anggota kaumnya. Pengaturan posisi tempat duduk membagi ruang lepas sebagai area penyantapan menjadi kelompok-kelompok peran ninik mamak, sumando, dan kemenakan di dalam keluarga berdasarkan sistem kekerabatan matrilinieal (Suarman dkk, 2000). Pembentukan kelompok ruang pada ruang lepas ketika proses penyantapan makanan memenuhi syarat lingkungan yang efektif yaitu "congruence with appropriate rules for behavior" (Rapoport, 1997). Ruang lepas yang merupakan ruang terbuka dapat memfasilitasi aturan adat yang berlaku yaitu tata cara duduk berdasarkan peran anggota keluarga sesuai dengan sistem kekerabatan matrilinieal. Elemen-elemen fisik dari bangunan rumah Gadang dan peralatan makan memenuhi syarat lingkungan efektif "cues in setting" (Rapoport, 1997) yang menjadi penanda terbentuknya pengelompokkan ruang pada area menyantap di ruang lepas. Pengelompokkan ruang ini terlihat dengan jelas ketika pelaksanaan kegiatan menyantap makanan terjadi.

\section{Peran kegiatan makan sebagai ruang sosial}

Sesuai dengan pepatah adat Minangkabau tentang budaya makan (Rekarti, 2003) yang telah disebutkan pada studi literatur, jamuan makan selalu diikutsertakan dalam musyawarah dan kesempatan lainnya. Hal ini menyebabkan jamuan makan sebagai saran komunikasi dan interaksi sosial bagi masyarakat Minangkabau. Interaksi sosial yang terbentuk terbagi sesuai dengan pembagian ruang-ruang dalam proses kegiatan makan dan orang yang berkegiatan di dalamnya.

Pada proses menyiapkan makanan pada setiap jenis kegiatan yang berlokasi di bagian 
belakang rumah terjadi interaksi sosial utama yaitu interaksi antara Bundo Kanduang dengan anak kemenakan perempuan dalam menuntun dan mengajarkan perihal permasalahan rumah tangga. Selain itu, juga terdapat interaksi sosial antara wanita di dalam keluarga dan tetangga yang ikut membantu dalam persiapan jamuan makan perayaan siklus hidup. Sedangkan pada proses menyantap makanan di ruang lepas sesuai dengan posisi tempat duduk berdasarkan hubungan para pria di dalam kekerabatan matrilinieal (Suarman dkk, 2000) ketika perayaan siklus hidup dan menjamu tamu di kehidupan sehari-hari, interaksi sosial antara pihak yang mengadakan acara dan para tamu adalah bentuk interaksi yang utama. Terdapatnya juga interaksi sosial antara Ninik Mamak dan anak kemenakan serta antara Ninik Mamak dan Sumando. Interaksi sosial yang terbentuk pada kedua area ini sesuai dengan pembagian peran wanita dan pria dalam jamuan makan dan tidak terjadi pencampuran interaksi sosial antara pria dan wanita.

Area penyimpanan di ruang dalam yang menghubungkan area persiapan di bagian belakang dan area penyantapan di depan rumah ditemukan memiliki nilai integrasi paling tinggi pada kegiatan makan $\mathrm{K} 1$ dan $\mathrm{K} 3$ serta pada $\mathrm{K} 2$, K4, dan $\mathrm{K} 5$ memiliki nilai integrasi tertinggi kedua. Hal ini menandakan bahwa ruang dalam terletak di tengah sistem sesuai dengan fungsinya sebagai ruang sirkulasi dan penghubung area-area lainnya. Pada ruang dalam ini pula ditemukan pencampuran interaksi sosial antara wanita dan pria, lebih tepatnya antara Bundo Kanduang dan Anak Pisang yang merupakan Raja Janang. Dari ruang dalam ini anak pisang akan mengambil makanan dengan arahan Bundo Kanduang dan menyajikannya ketika acara sedang berlangsung. Hal ini sesuai dengan aturan hubungan sistem kekerabatan matrilinieal di Minangkabau (Suarman dkk, 2000) yaitu Bundo Kanduang bertanggung jawab untuk berkomunikasi dengan kemenakan lelaki dari saudara laki-lakinya.

Secara keseluruhan dengan bersumber dari pepatah adat Minangkabau dan sistem kekerabatan matrilinieal, ruang-ruang dalam budaya makan merupakan ruang sosial 
tempat terjadinya hubungan sosial antar pelaku tiap tahapan proses kegiatan makannnya. Hubungan ruang dan budaya makan pada masyarakat Minangkabau sebagai ruang sosial memenuhi syarat efektif lingkungan fisik (Rapoport, 1977) yaitu "consideration of latent aspect of activities" dan "relation to other settings lead to the greater use". Kegiatan makan sebagai kegiatan sosial merupakan aspek tersembunyi dapat terfasilitasi dengan baik di dalam ruang-ruang di rumah Gadang. Selain itu, terbentuknya ruang sosial ini terjadi di seluruh area proses kegiatan makan yang sesuai dengan peran wanita dan pria dalam sistem kekerabatan Minangkabau. Hubungan antar ruang-ruang di rumah Gadang yang digunakan saling terhubung dengan baik sehingga mempermudah ruang gerak dalam melakukan proses kegiatan makan.

\section{PENUTUP}

Penelitian ini menemukan bahwa tata ruang pada Rumah Gadang telah dengan efektif memenuhi syarat-syarat dalam memfasilitasi budaya makan pada perayaan siklus hidup dan kehidupan sehari-hari masyarakatnya. Terdapat beberapa hubungan antara ruang dan budaya makan dalam siklus hidup masyarakat Minangkabau berdasarkan adat istiadatnya yaitu sebagai berikut.

a. Pembagian ruang dalam proses pelaksanaan kegiatan makan disesuaikan dengan peran wanita dan pria berdasarkan sistem kekerabatan matrilinieal. Hal ini didukung oleh hasil perhitungan dengan menggunakan teknik analisis space syntax.

b. Ruang lepas sebagai area penyantapan terbagi menjadi kelompokkelompok ruang yang lebih kecil sesuai dengan pengaturan posisi tempat duduk para pria Minangkabau berdasarkan sistem kekerabatan matrilinieal. Kelompok-kelompok ruang ini ditandai oleh dinding, kolom, dan kain seprah alas makanan.

c. Seluruh ruang-ruang tempat pelaksanaan kegiatan makan merupakan ruang 
sosial tempat terjadinya interaksi sosial yang mencerminkan pepatah adat Minangkabau.

Selain itu, penggunaan teknik analisis space syntax terbukti dapat digunakan dalam mempelajari dan memperjelas hubungan antara ruang dan kegiatan berbudaya. Namun, pada konteks ruang yang lebih kecil dan spesifik seperti pada pengelompokan ruang yang lebih kecil pada satu ruang besar dan perbedaan ruang karena ketinggian lantai, teknik analisis space syntax yang digunakan belum dapat menguraikan fenomena yang terjadi sehingga perlu ditambahkan pada dimensi-dimensi lainnya.

\section{DAFTAR PUSTAKA}

Díaz-Méndez, C., van den Broek, H. (2017). Eating out in modern societies: An overview of a heterogeneous habit. Appetite, 119, 1-4. https://doi.org/10.1016/j.appet.2017.05.003

Franzia, E., Piliang, Y., Saidi, A. (2015). Rumah Gadang as a Symbolic Representation of Minangkabau Ethnic Identity. International Journal of Social Science And Humanity, 5(1), 44-49. https://doi.org/10.7763/ijssh.2015.v5.419

Goodman, M., Johnston, J., Cairns, K. (2017). Food, media and space: The mediated biopolitics of eating. Geoforum, 84, 161-168. https://doi.org/10.1016/j.geoforum.2017.06.017

Lipoeto, N., dkk (2001). Contemporary Minangkabau food culture in West Sumatra, Indonesia. Asia Pacific Journal of Clinical Nutrition, 10(1), 10-16. https://doi.org/10.1046/j.1440-6047.2001.00201.x

Maximillian, A. (2013). Korelasi Interior Restoran Italia dengan Restoran dan Cafe Bergaya Italia di Bandung. Tesis Jurusan Desain Institut Teknologi Bandung, Bandung.

Mintosih, S., Widiyanto, Y. (1996). Tradisi dan Kebiasaan Makan pada Masyarakat Tradisional di Kalimantan Barat. Ed. 1, Direktorat Sejarah dan Nilai Tradisional, Direktorat Jenderal Kebudayaan, Departemen Pendidikan dan Kebudayaan. 
Newman, J. (2009). The linguistics of eating and drinking. John Benjamins Pub. Co.

Nurmufida, M., Wangrimen, G., Reinalta, R., \& Leonardi, K. (2017). Rendang: The Treasure of Minangkabau. Journal of Ethnic Foods, 4(4), 232-235. https://doi.org/10.1016/j.jef.2017.10.005

Nurti, Y. (2013). Perubahan Budaya Makan pada Orang Minangkabau : Suatu Kajian Kasus pada Acara Baralek Gadang di Kota Padang. Disertasi Jurusan Antropologi Universitas Indonesia, Depok.

Probyn, E. (2017). Eating/space/media. Geoforum, 84, 243-244. https://doi.org/10.1016/j.geoforum.2017.06.020

Rapoport, A. (1977). Human Aspects of Urban Form. Pergamon Press.

Rekarti, E. (2003): Hiper-Realitas pada Rumah Makan Padang Kecenderungan Konsumen Tidak Lagi Memperhatikan Keaslian Suatu Produk, Diunduh 14 April 2014 dari http://portal.kopertis3.or.id/bitstream/123456789/1093/1/HIPERREALITAS\%2OPAD A\%20RUMAH\%20MAKAN\%20PADANG\%20Kecendrungan\%20konsumen\%20tidak \%20lagi\%20memperhatikan\%20keaslian\%20suatu\%20produk.pdf.

Sari, N. (2000). Alat Santap - Kajian Desain dalam Konteks Budaya Makan Orang Sunda Masa Kini di Bandung, Tesis Jurusan Desain Institut Teknologi Bandung, Bandung. Siregar, J. (2014). Metodologi Dasar Space Syntax dalam Analisis Konfigurasi Ruang. Diunduh 28 Juni 2020 dari http://johannes.lecture.ub.ac.id/files/2014/03/Modul01-space-syntax-metodologi-dasar-sapace-syntax.pdf.

Suarman., Arifin, B., Chan, S. (2000). Adat Minangkabau - Nan Salingka Hiduik

Surya, V., Gabe, R. (2015). In Dwelling : The Tradition of Eating Activities on Urban Minangnese. Dipresentasikan pada International Conference on Dwelling Form, Lombok, Indonesia. 

Serat Rupa Journal of Design, January 2020, Vol.4, No.1: 01-15

E-ISSN: 2477-586X, ISSN: 2338-3348 | https://doi.org/10.28932/srjd.v4i1.2012 | Received: 30- 10- 2019, Accepted: 16- 01- 2020

Mahimma Romadhona, Aileena Solicitor Costa Rica El Chidtian, Roziana Febrianita

Kajian Bela Negara Pada Desain Kostum dan Atribut Superhero Panca Satria 